\title{
Cytokine profile during occult hepatitis B virus infection in chronic hepatitis $C$ patients
}

\author{
Camilla Rodrigues de Almeida Ribeiro' ', Nathalia Alves Araújo de Almeida' , Katrini Guidolini Martinelli², \\ Marcia Amendola Pires ${ }^{3}$, Carlos Eduardo Brandao Mello ${ }^{3}$, José J. Barros ${ }^{1 *}$ and Vanessa Salete de Paula
}

\begin{abstract}
Background: The hepatitis B virus (HBV) is one of the leading causes of acute, chronic and occult hepatitis (OBI) representing a serious public health threat. Cytokines are known to be important chemical mediators that regulate the differentiation, proliferation and function of immune cells. Accumulating evidence indicate that the inadequate immune responses are responsible for HBV persistency. The aim of this study were to investigate the cytokines IFN- $\gamma_{\text {, }}$ TNF-a, IL-2, IL-4, IL-6, IL-10 and IL-17A in patients with OBI and verify if there is an association between the levels of these cytokines with the determination of clinical courses during HBV occult infection.

Methods: 114 patients with chronic hepatitis $C$ were investigated through serological and molecular tests, the $\mathrm{OBI}$ coinfected patients were subjected to the test for cytokines using the commercial human CBA kit. As controls, ten healthy donors with no history of liver disease and 10 chronic HBV monoinfected patients of similar age to OBI patients were selected.

Results: Among 114 HCV patients investigated, 11 individuals had occult hepatitis B. The levels of cytokines were heterogeneous between the groups, most of the cytokines showed higher levels of production detection among $\mathrm{OBI} / \mathrm{HCV}$ individuals when compared to control group and HBV monoinfected pacients. We found a high level of IL17A in the HBV monoinfected group, high levels of TNF-a, IL-10, IL-6, IL-4 and IL-2 in OBI/HCV patients.

Conclusion: These cytokines could be involved in the persistence of HBV DNA in hepatocytes triggers a constant immune response, inducing continuous liver inflammation, which can accelerate liver damage and favor the development of liver cirrhosis in other chronic liver diseases.
\end{abstract}

Keywords: Occult hepatitis B infection, Cytokines, HBV/HCV co-infection

\section{Background}

Hepatitis B virus (HBV) affects 2 billion people worldwide. Of these, approximately 350 million have a chronic infection with a risk of developing a serious condition, with cirrhosis and hepatocellular carcinoma (HCC), which cause 500 to 700 thousand deaths per year in the world $[1,2]$. The disease caused by the HBV can result

\footnotetext{
*Correspondence: barros@ioc.fiocruz.br

1 Laboratory of Molecular Virology, Oswaldo Cruz Institute, Oswaldo Cruz Foundation, 4365, Brasil Av., Manguinhos, Rio de Janeiro, RJ 21040-360, Brazil

Full list of author information is available at the end of the article
}

in asymptomatic infection, acute self-limiting hepatitis, chronic hepatitis, fulminant hepatitis, occult HBV infection $(\mathrm{OBI})$ and in more severe cases requires liver transplantation [3].

The persistence of replication-competent HBV DNA (i.e. episomal HBV covalently closed circular DNA [cccDNA]) in the liver tissue and/or blood of patients with negative results for the hepatitis $B$ surface antigen ( $\mathrm{HBsAg})$ antigen by currently available assays is called occult HBV infection [4-6]. It can occur after the resolution of a self-limited acute infection or after a long time of infection, if there is any clinical evidence or biochemical change in liver function, using these virus carriers, original author(s) and the source, provide a link to the Creative Commons licence, and indicate if changes were made. The images or other third party material in this article are included in the article's Creative Commons licence, unless indicated otherwise in a credit line to the material. If material is not included in the article's Creative Commons licence and your intended use is not permitted by statutory regulation or exceeds the permitted use, you will need to obtain permission directly from the copyright holder. To view a copy of this licence, visit http://creativecommons.org/licenses/by/4.0/. The Creative Commons Public Domain Dedication waiver (http://creativeco mmons.org/publicdomain/zero/1.0/) applies to the data made available in this article, unless otherwise stated in a credit line to the data. 
with a potential risk of transmitting the infection $[5,7,8]$. In this context, the antibody against the viral core (anti$\mathrm{HBc}$ ) should be considered to investigating patients for OBI $[9,10]$.

There are three types of OBI: seropositive, seronegative and a case called "false". Seropositive OBI is characterized by the detection of anti-HBc antibody with or without anti-HBs. The OBI seronegative is characterized by undetectable antibodies both anti-HBc and anti-HBs. OBI seropositive is responsible for the vast majority of $\mathrm{OBI}$ cases, which can be attributed to the higher proportion of resolved HBV infections. However, more than $20 \%$ of individuals with OBI do not have serological markers, either due to the drop-in antibody titers over time that become undetectable, or because there has never been seroconversion, this latter case is known as OBI seronegative [11]. Thus, OBI can be found both in seropositive individuals (with the presence of anti-HBc accompanied or not by anti-HBs), and in seronegatives, making HBVDNA the only marker of HBV infection, detectable at low levels $(<200 \mathrm{IU} / \mathrm{mL})$ [5]. "False" OBI occurs due to the presence of mutations in the $S$ gene (escape mutants) that produce modified HBsAg that are not recognized by commercially available detection assays [11-13].

Although the clinical implications are almost minimal in patients with OBI, the biggest concern is the fact that transmission to healthy people even with very low viral load values. There is also the possibility or ability to reactivate viral replication in the presence immunosuppression, which can lead to severe acute conditions and liver decompensation with high mortality $[6,14]$.

The mechanisms involved in the pathogenesis of OBI have been the subject of several studies, but they still need to be clarified. The pathogenesis of OBI can be multifactorial depending largely on the virus-host interaction, mediated by the immune response [15]. Several evidences demonstrate that the virus-host interactions are related to the induction and maintenance of the occult phase of infection by the hepatitis $B$ virus. The host's immune response is linked to viral persistence and the immunopathogenesis of the infection [16]. Concomitant hepatitis $\mathrm{C}$ virus (HCV) infection and other risk factors, such as alcohol consumption, are also associated with occult HBV infection that can progress to chronic liver disease [17]. HBV reactivation has been reported in patients with chronic $\mathrm{HCV}$ infection under treatment with more recent direct-acting antivirals (DAA), resulting in fulminant hepatitis, liver failure and, in some cases, death [18].

The prevalence of OBI among patients with chronic hepatitis $\mathrm{C}(\mathrm{CHC})$ varies widely from 0 to $52 \%$ [19]. HBV can maintain its oncogenic potential in all clinical situations of the course of its infection, including OBI and it is estimated that the existence of other causes that lead to liver damage, such as HCV co-infection, accelerate this process [20]. Some studies indicate that OBI unfavorably affects the progression of liver fibrosis and the development of HCC in patients with CHC [21-23].

There are clear differences in adaptive immunity in patients with chronic or resolved HBV infection. The responses of $\mathrm{HBV}$-specific $\mathrm{CD} 4+$ and $\mathrm{CD} 8+\mathrm{T}$ cells with a Th1 cytokine production profile are detectable in high blood titers in individuals with a favorable outcome. These Th1 cell responses along with cytotoxic responses are quantitatively stronger than those found in patients with chronic infections, which are, on the contrary, characterized by weaker or undetectable $\mathrm{T}$ cell responses to the virus [24-27].

Differences between the host's immune response may be one of the reasons for the development and progression of hepatitis B $[28,29]$. Cytokines represent a large family of molecules, including cytokines associated with type 1 (Th1) T cell responses (eg, interleukin (IL-2), interferon (IFN- $\gamma$ )), which have a functional contribution to cell immune responses; type 2 (Th2) T cell response (eg, IL-4, IL-6, IL-10), which play a role in humoral immune responses; cytokines associated with regulatory $\mathrm{T}$ cells (Treg) with, for example, IL-10 which is associated with immunomodulation and immunosuppression; and T-cell response of type 17 (Th17) (for example, IL-17), which play critical roles in mediating inflammation [30].

Here we investigated the cytokines IFN- $\gamma$, TNF- $\alpha$, IL-4, IL-6, IL-10 and IL-17A that have a great impact on the clinical outcomes associated with hepatitis B. However, this impact is still not well understood and some cytokines such as IFN-Y, IL-6, IL-2 and IL-4 have a controversial role in HBV infection, which may induce cirrhosis and $\mathrm{HCC}$ or eliminate $\mathrm{HBV}$ via inducing humoral and cellular immune response [28, 31-33]. Cytokines such TNF- $\alpha$, IL-10 and IL-17A are well described in association with chronic hepatitis, cirrhosis and HCC in combination with other proinflammation cytokines [34-36].

The aim of this study was to investigate the presence of pro and anti-inflammatory cytokines IFN- $\gamma$, TNF- $\alpha$, IL-2, IL-4, IL-6, IL-10 and IL-17A in patients with occult hepatitis $B$ and to verify if there is an association between the levels of these cytokines with the determination of clinical courses during HBV occult infection.

\section{Materials and methods Population Studied}

This is a retrospective cross-sectional study conducted in patients prior to commencement of DAA treatment who had attended the Outpatient Clinic of Liver Disease at the Gaffrée and Guinle University Hospital (Rio 
de Janeiro, Brazil) from January to December 2018. All patients enrolled into the study signed an informed consent form after being provided all necessary information to make an informed decision. Socio-epidemiological data, information about infection, HBV treatment and risk behaviors were obtained from each patient record or from the questionnaire.

Serum samples were collected from a cohort of 114 consecutive $\mathrm{HCV}$ patients. All serum samples were HCV RNA-positive and examined for total anti-HBc and HBsAg via immunoenzymatic assays (EIA). Samples positive for anti-HBc with no HBsAg indicating seropositive OBI were further examined using real-time PCR (qPCR) and nested PCR [37]. The HBV DNA was additionally sequenced for genotyping, HBV genotyping was performed by phylogenetic analyses of the pre-S/S gene with HBV sequences representing all genotypes available in GenBank. Phylogenetic analysis was performed using the maximum likelihood method with the online version of the PhyML program [38]. The reliability of the phylogenies was estimated with the approximate likelihood-ratio test [39] based on a Shimodaira-Hasegawa-like procedure (SH-aLRT).

Occult infections were considered as those with viral DNA in the serum tissue of HBsAg-negative individuals. Of the $114 \mathrm{HCV}$ patients, 11 individuals had occult hepatitis B and were included in this study. As controls, ten healthy donors with no history of liver disease and 10 chronic HBV monoinfected patients of similar age to $\mathrm{OBI} / \mathrm{HCV}$ patients were selected.

\section{Biochemical tests}

Serum samples were subjected to biochemical doses of liver enzymes, such as aspartate aminotransferase (AST); alanine aminotransferase (ALT); alkaline phosphatase; total, direct and indirect bilirubin; and gamma-glutamyl transferase (GGT) through a system of quantitative determination by photometry in kinetic mode using a commercial kit (LabMax 560, LabTest, Minas Gerais, Brazil) according manufacture instructions.

\section{Cytokine quantification}

Peripheral blood obtained was centrifuged on $800 \mathrm{~g}$ for $10 \mathrm{~min}$ at room temperature. Sera was collected and stored at $-70{ }^{\circ} \mathrm{C}$ until test performance. The serum levels of IL-2, IL-4, IL-6, IL-10, TNF- $\alpha$, IFN- $\gamma$, and IL17A were determined by means of flow cytometry with a BD Cytometric Bead Array (CBA) Human Th1/Th2/Th17 Cytokine Kit (BD Biosciences San Jose, CA), following the manufacturer's technical guidelines and protocols. A FACS Canto II flow cytometer (BD Biosciences, NJ, USA) was used for sample acquisition, and FCAP-Array software (ver. 3.0.1) was used to calculate cytokine levels and the mean fluorescence intensity of each cytokine.

\section{Data analysis}

The SPSS 2.0 program was used to perform the statistical analyzes. Descriptive statistics of the qualitative variables was determined by frequency distribution and quantitative variables by median and P25-75. Afterwards, the normality of data distribution was assessed by the Kolmogorov-Smirnov test. The Mann-Whitney nonparametric test was used to compare cytokine levels between the groups. Correlation was estimated by Spearman test (the data did not present a normal distribution). Values of $p \leq 0.05$ and $95 \%$ confidence intervals (CIs) were considered as significant for all statistical analysis. Graphs were built using Graphpad 5.0 (Graphpad software, San Diego, CA, USA).

\section{Ethical approval}

The study protocol was approved by the Research Ethics Committee of the Institute Oswaldo Cruz (CAAE 34246914.4.1001.5248 number 2.927.747/18).

\section{Results \\ Sociodemographic and bioclinical characteristics of the study population}

Occult HBV infection was detected in eleven patients $(9,64 \%)$. The majority of the OBI patients was woman $(54.5 \%)$ with a mean age of $65.17 \pm 9.57$. The patients had received treatment with pegylated interferon $(80 \mathrm{mcg})$ and ribavirin (1.0 g per day) for 24 weeks without $\mathrm{HCV}$ clearance. No patients developed ALT and AST flareups and all were anti-HB-positive, with viral loads ranging from 207.14 to $266,114.8 \mathrm{IU} / \mathrm{mL}\left(8.5 \times 10^{2}\right.$ to $1.49 \times 10^{8}$ copies $/ \mathrm{mL}$ ). Patients with the highest viral loads were positive for S-region amplification via nested-polymerase chain reaction (nested-PCR) and HBV in these cases was classified as genotype A (A1 and A2 subtypes) (Additional file 1: Table 1).

Nine patients had chronic active hepatitis $\mathrm{C}$, grade 4, with cirrhosis (F4, 14.1-46.4 $\mathrm{kPa}$; fibroscan), and two patients had chronic active hepatitis $\mathrm{C}$, grade 2, with cirrhosis (F2, 6.8-6.9 $\mathrm{kPa}$; fibroscan). After the study, all patients were re-treated with sofosbuvir $(400 \mathrm{mg})+$ daclatasvir $(60 \mathrm{mg})+$ ribavirin $(1.0 \mathrm{~g})$, following which $\mathrm{HCV}$ remained undetectable. Information on gender, age distribution, viral load and genotype distribution of the OBI patients are described in Table 1 . No correlation was found between liver enzymes (ALT and AST), the patients age and viral load of HBV or HCV. 
Table 1 Demographic and clinical data in patients infected with HCV and occult hepatitis B. Rio de Janeiro, 2018

\begin{tabular}{|c|c|c|}
\hline Categorical variables & $\mathbf{N}$ & $\%$ \\
\hline \multicolumn{3}{|l|}{ Gender } \\
\hline Female & 06 & 54.5 \\
\hline Male & 05 & 45.5 \\
\hline \multicolumn{3}{|l|}{ Fibrosis stage } \\
\hline $\mathrm{F} 2$ & 02 & 18.2 \\
\hline F4 & 09 & 81.8 \\
\hline \multicolumn{3}{|l|}{ Genotype HCV } \\
\hline $1 a$ & 05 & 45.5 \\
\hline $1 b$ & 04 & 36.4 \\
\hline $3 a$ & 02 & 18.2 \\
\hline \multicolumn{3}{|l|}{ Genotype HBV } \\
\hline $\mathrm{A} 1$ & 01 & 9.1 \\
\hline$A 2$ & 02 & 18.2 \\
\hline ND & 08 & 72.7 \\
\hline Continuos variables & Mean & SD \\
\hline Age (years) & 65.64 & 6.89 \\
\hline Viral Load (log) & 3.36 & 1.01 \\
\hline $\mathrm{ALT}^{*}$ & 62.91 & 29.92 \\
\hline $\mathrm{AST}^{*}$ & 72.09 & 41.95 \\
\hline $\mathrm{GGT}^{*}$ & 76.64 & 64.02 \\
\hline$B T^{*}$ & 0.67 & 0.27 \\
\hline Copies/mL_-HBV & $1.76 \mathrm{E}+07$ & $4.56 \mathrm{E}+07$ \\
\hline $\mathrm{IU} / \mathrm{mL}^{* *}$ & $32,851.90$ & $80,988.23$ \\
\hline Continuos variables & Median & P25-75 \\
\hline Age (years) & 66 & $62-69$ \\
\hline Viral Load (log) & 3.26 & $2.61-3.71$ \\
\hline $\mathrm{ALT}^{*}$ & 68 & $39-76$ \\
\hline $\mathrm{AST}^{*}$ & 71 & 33-109 \\
\hline $\mathrm{GGT}^{*}$ & 65 & $38-94$ \\
\hline$B T^{*}$ & 0.80 & $0.40-0.90$ \\
\hline Copies/mL_-HBV & $1.03 E+04$ & $2.26 \mathrm{E}+03-8.50 \mathrm{E}+04$ \\
\hline$|\mathrm{U} / \mathrm{ml}|^{* *}$ & 1839.5 & $403-5178.1$ \\
\hline
\end{tabular}

SD standard deviation, ND not determined, $P 25$ 25th percentile, $P 75$ 75th percentile

${ }^{*}$ AST (alanine aminotransferase)—Reference values in chronic hepatitis:<31 U/L (women) and $37 \mathrm{U} / \mathrm{L}$ (men); ${ }^{*} \mathrm{ALT}$ (alkaline phosphatase)—Reference values in chronic hepatitis:<31 U/L (women) and < $41 \mathrm{U} / \mathrm{L}$ (men); *GGT (gamma-glutamyl transferase) - Reference values 8-61 U/L (men) and 5-36 U/L (women); *BT (total **1 copies/ $\mathrm{ml}$. corresponds to $5.26 \mathrm{IU} / \mathrm{ml}$ )

\section{Expression levels of cytokines}

Although, most of the patients were female and belonged to HCV genotype 1a no correlation was found in the cytokine levels, gender, liver enzymes (ALT and AST), age and HBV or HCV viral load.

In the present study, a significant difference was found in the medians, we found higher medians of IL17-A in the HBV monoinfected group; a significant difference was found for IL-17A $(p=0,0317)$ between the $\mathrm{OBI} / \mathrm{HCV}$ and HBV monoinfected groups.
TNF- $\alpha(p=0.020)$, IL-6 $(p<0.0001)$, IL-4 $(p=0.024)$ and IL-2 $(p=0.043)$ were higher in the OBI/HCV group and no significant difference was found for INF-Y $(p=0.512)$ and IL-10 $(p=0.114)$ compared to the controls. A significant difference was found for IL-6 $(p=0,0014)$ between the OBI/HCV and HBV monoinfected groups and no significant difference was found between HBV monoinfected and controls for all analyzed cytokines (Table 2). 
Table 2 Median values $(\mathrm{pg} / \mathrm{mL})$ of cytokines in each group

\begin{tabular}{|c|c|c|c|c|c|c|}
\hline \multirow[t]{2}{*}{ Citokyne } & \multicolumn{2}{|l|}{ Control } & \multicolumn{2}{|l|}{$\mathrm{OBI} / \mathrm{HCV}$} & \multicolumn{2}{|c|}{ HBV } \\
\hline & Median & P25-P75 & Median & P25-P75 & Median & P25-P75 \\
\hline IL-17A & $10.36^{a}$ & $7.92-12.67$ & $6.38^{a, b}$ & $1.34-8.26$ & $10.91^{b}$ & $6.54-16.43$ \\
\hline INF-Y & 0.43 & $0.0-0.65$ & 0.43 & $0.0-5.32$ & 0.05 & $0.0-0.23$ \\
\hline TNF-a & $0.0^{\mathrm{a}}$ & $0.0-0.99$ & $2.77^{\mathrm{a}}$ & $1.02-24.80$ & 0.00 & $0.00-13.74$ \\
\hline IL-10 & 0.25 & $0.12-0.56$ & 2.38 & $0.0-2.74$ & 0.58 & $0.01-3.40$ \\
\hline IL-6 & $0.67^{a}$ & $0.43-1.76$ & $9.76^{a, b}$ & $7.51-23.33$ & $1.43^{b}$ & $0.76-4.18$ \\
\hline$\| L-4$ & $2.22^{\mathrm{a}}$ & $1.54-2.97$ & $6.14^{\mathrm{a}}$ & $1.87-20.98$ & 1.82 & $1.43-13.00$ \\
\hline $\mid \mathrm{L}-2$ & $0.0^{\mathrm{a}}$ & $0.0-1.11$ & $1.22^{\mathrm{a}}$ & $0.0-8.64$ & 0.06 & $0.0-8.23$ \\
\hline
\end{tabular}

25th percentile (P25) and 75th percentile (P75) according to different levels of cytokines. To know the difference between the groups, the Mann-Whitney nonparametric test was used. Equal letters show groups with statistically significant mean difference

The mean values of IL-6 $(p=0.025)$ and IL-4 $(p=0.045)$ were higher in the $\mathrm{OBI} / \mathrm{HCV}$ group when compared to the controls group, and no significant difference was found for IFN-Y $(p=0.086)$. However, when comparing the mean values of the measured cytokines, we found that unlike the median, the mean values of IL-10 $(p=0.031)$ were higher in $\mathrm{OBI} / \mathrm{HCV}$ group, and no significant difference was found for IL-2 $(p=0.076)$ and TNF- $\alpha$ ( $p=0.133)$.

We found higher medians of IL-17-A in the HBV monoinfected group; a significant difference was found for IL-17A $(p=0,0246)$ between the OBI/HCV and HBV monoinfected groups. A significant difference was found for IL-6 $(p=0,0011)$ between the OBI/HCV and HBV monoinfected groups and no significant difference was found between HBV monoinfected and controls for all analyzed cytokines (Fig. 1 and Table 3 ).

The correlation between cytokines products were analyzed to understand the possible relationship between them. It was possible to observe that there is a positive correlation between cytokines, IFN-Y vs TNF- $\alpha$ $(p=0.041)$, IFN-Y vs IL-10 $(p=0.032)$, IFN-Y vs IL-4 $(p=0.013)$, IFN-Y vs IL-2 $(p=0.003)$, TNF vs IL-2 $(p=0.003)$ and IL4 vs IL-2 $9(p=0.002)$. The correlations found are classified as moderate to strong. No significant correlations were observed for IL-17A and IL-6 (Table 4).

\section{Discussion}

Antiviral immune responses in OBI are continuously stimulated by persistent/intermittent low concentrations of HBV antigens and cytokines can play an important role in controlling HBV replication [6]. In this present study, the levels of cytokines in $\mathrm{OBI} / \mathrm{HCV}$ patients were heterogeneous, showing dissemination over a wide range of values with high standard deviations, which can be attributed to the different genotypes and a wide range of viral loads, however, due to the low number of samples, it was not possible to confirm this correlation between genotypes, viral load and the cytokines studied. In the present study, the prevalence of OBI in patients with $\mathrm{CHC}$ was $9.6 \%$. Previous studies analyzing serum samples of Brazilian HCV infected patients found frequencies of OBI ranging from 0 to $24 \%$ [40-46].

OBI patients usually have a low viral load with suppression of HBV replication and thus, most OBI patients have normal liver histology or minimal fibrosis. However, they are still at risk of developing liver cirrhosis. The prevalence of OBI in cirrhotic patients varies widely from 4 to $38 \%$ between different regions of the world [22, 47].

The persistence of HBV DNA in hepatocytes triggers a constant immune response, inducing mild but continuous liver inflammation, which can accelerate liver damage and favor the development of liver cirrhosis in other chronic liver diseases, such as in patients with chronic hepatitis $C[22,48-50]$. OBI can contribute to the development of HCC under direct and indirect mechanisms similar to those of chronic HBV infection [51].

In addition, the presence of OBI/HCV coinfection is believed to have an adverse effect on the response to treatment in IFN-based therapies [52]. Coinfection with $\mathrm{OBI} / \mathrm{HCV}$ was associated with decreased intrahepatic expression of interferon receptor mRNA (IFNAR2), higher levels of serum HCV RNA and a poor IFN response, regardless of the HCV genotype. These results suggest the possibility that coinfection is one of the factors that can lead to an unfavorable IFN response in chronic hepatitis $C$ by negative regulation of the IFN receptor gene expression in the liver [53].

Levels of alanine aminotransferase (ALT) are generally slightly higher in occult hepatitis B in HCV co-infection, with averages ranging from 39 to $158 \mathrm{IU} / \mathrm{mL}[54,55]$. In our study we found a mean of 62.91 ALT IU/ml, but no correlation was found between the levels of ALT/AST at the age, viral load and the analyzed cytokines.

ALT levels correlate well with inflammatory activity on biopsy, which is generally mild [56]. However, in contrast 

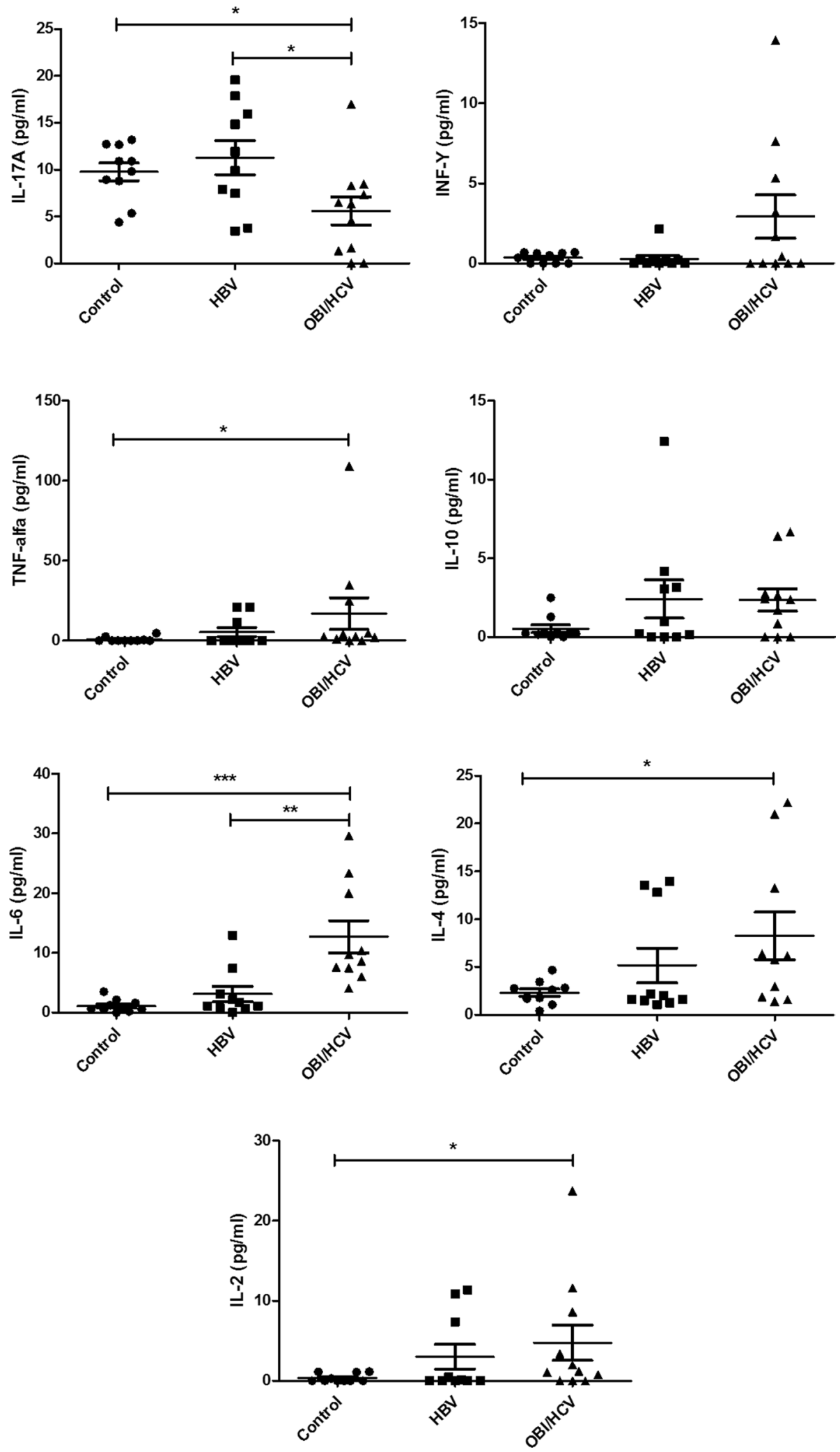

Fig. 1 Expression medians levels of inflammatory cytokines in serum from various clinical states of hepatitis B virus infection and controls. Mann Whitney non-parametric test was used to analyze the differences between the groups. ${ }^{*} p<0.05$; ${ }^{* *} p=0.001{ }^{* * *} p<0.0001$ 
Table 3 Mean \pm standard deviation $(\mathrm{pg} / \mathrm{mL})$ values of cytokines in each group

\begin{tabular}{lcllllll}
\hline & IL-17A & IFN-Y & TNF-a & IL-10 & IL-6 & IL-4 & IL-2 \\
\hline OBI/HCV group & $5.58 \pm 4.96^{\mathrm{a}, \mathrm{b}}$ & $2.92 \pm 4.46$ & $16.87 \pm 32.61$ & $2.34 \pm 2.33^{\mathrm{a}}$ & $18.99 \pm 22.39^{\mathrm{a}, \mathrm{b}}$ & $11.63 \pm 13.43^{\mathrm{a}}$ & $4.76 \pm 7.35$ \\
Control group & $9.76 \pm 3.00^{\mathrm{a}}$ & $0.35 \pm 0.32$ & $0.78 \pm 1.60$ & $0.53 \pm 0.78^{\mathrm{a}}$ & $1.12 \pm 1.06^{\mathrm{a}}$ & $2.31 \pm 1.22^{\mathrm{a}}$ & $0.37 \pm 0.53$ \\
HBV group & $11.26 \pm 5.69^{\mathrm{b}}$ & $0.28 \pm 0.65$ & $5.32 \pm 8.97$ & $2.41 \pm 3.84$ & $3.11 \pm 4.04^{\mathrm{b}}$ & $5.16 \pm 5.72$ & $3.01 \pm 4.83$ \\
\hline
\end{tabular}

To know the difference between the groups, the Mann-Whitney nonparametric test was used. Equal letters show groups with statistically significant mean difference

Table 4 Correlation between cytokines in OBI/HCV group through Spearman's correlation coefficient

\begin{tabular}{|c|c|c|c|c|c|}
\hline & IFN-Y & TNF-a & IL-10 & IL-4 & IL-2 \\
\hline IFN-Y & & $\begin{array}{l}r O ̂=0.621 \\
p=0.041\end{array}$ & $\begin{array}{l}\text { rô }=0.645 \\
p=0.032\end{array}$ & rô $=0.715 p=0.013$ & rô $=0.808 p=0.003$ \\
\hline TNF-a & & & rô $=0.267 p=0.428$ & $\begin{array}{l}\text { rô }=0.888 \\
p=2.57\end{array}$ & rô $=0.795 p=0.003$ \\
\hline $\mid \mathrm{L}-10$ & & & & rô $=0.294 p=0.381$ & rô $=0.389 p=0.237$ \\
\hline |L-4 & & & & & rô $=0.826 p=0.002$ \\
\hline
\end{tabular}

to this mild inflammation, most studies have shown an increased prevalence of fibrosis/advanced cirrhosis in patients with occult hepatitis B [56-58]. These findings corroborate those of the present study, in which $81.8 \%$ of $\mathrm{OBI} / \mathrm{HCV}$ patients demonstrated stage F4 of fibrosis.

There are few studies on cytokine production profile in occult hepatitis $\mathrm{B}$ patients and the mechanism of liver injury due to OBI is still unclear, but some studies describe that the persistence and transcription of HBV cccDNA in hepatocytes can lead to the production of cytokines, such as TNF- $\alpha$ and INF- $\gamma$, which can result in damage for hepatocytes $[59,60]$. A reduction in proinflammatory cytokines, such as TNF- $\alpha$, was observed in patients who resolved HBV infection when compared to healthy individuals [59], and IFN- $\gamma$ was noticeably decreased, especially in monoinfected patients with $\mathrm{HCV}$ genotype $1 \mathrm{~b}$ [61]. In our study, we found higher medians for TNF- $\alpha$ in the OBI/HCV group and no significant difference was found between groups for INF-Y. Most of the patients in our study show stage F4 of fibrosis, which indicates very advanced fibrosis, occult HBV together with the $\mathrm{HCV}$ could be contributing to the increase of these cytokines and aggravating the fibrosis condition in these individuals. It is well known that TNF- $\alpha$ is involved with liver inflammation and hepatocytes injury and mediates viral hepatitis complications [32]. However, in this study, the stage F4 cannot be attributed only to OBI, the presence of $\mathrm{HCV} / \mathrm{HBV}$ infection can be an important role in the advanced fibrosis.

In our study, we found a significant increase in the median of IL-2 in OBI/HCV patients when compared to healthy controls, other studies find overexpression of IL-2 exclusively in patients infected with OBI when compared to healthy individuals and patients who have resolved HBV infection [62] and in patients monoinfected with HCV [63]. IL-2 plays an important role in the efficient development of effector cytotoxic CD8 $+\mathrm{T}$ cells, effector cells with a high expression of receptors for IL-2 (IL-2R) are cells that cause direct damage to the liver [64].

Unfortunately, in our study, was not possible to evaluate the cytokines levels in patients monoinfected with HCV. However, a study conducted by Baskic and collegues, 2017 [65] investigating the cytokine profile in chronic hepatitis $\mathrm{C}$ demonstrated that median levels of IL-17A were lower in patients with $\mathrm{HCV}$ than in controls. In our study, low levels of IL-17A were also found in $\mathrm{OBI} / \mathrm{HCV}$ coinfected patients. We found significant difference between $\mathrm{OBI} / \mathrm{HCV}$ compared to monoinfected HBV group and healthy controls with higher means in the monoinfected patients with HBV. The roles of IL-17A in inducing appropriate immune responses against viral infections are controversial, IL-17 may play a positive role in antiviral immune responses in several diseases [66]. However, for chronic hepatitis B, is well known, that IL-17A is positively regulated in HBV-mediated inflammation and may be relevant for the development of liver cirrhosis and HCC $[36,67,68]$. IL-17A can also significantly stimulate monocytes and DCs to express their ligand (IL-17R) and produce pro-inflammatory cytokines such as IL-1 $\beta$, TNF- $\alpha$, IL-6, etc., which are important for liver damage during progression of chronic hepatitis $B$ [69].

Other cytokines possibly involved in OBI include increased interleukin 10 (IL-10), IL-10 can leads to reduced expression of IL-12, stromal cell-derived factor (SDF)-1 $\alpha$, and $\mathrm{C}-\mathrm{C}$ chemokine receptor (CCR), which 
leads to the interruption of $\mathrm{T}$ and natural killer cells (NK cell) activation and the recruitment of immune cells to the infected liver [70]. IL-10 production is also increased in monoinfected patients with chronic hepatitis $\mathrm{C}$, the HCV RNA load is closely associated with IL-10 expressions, and inhibition of HCV replication was accompanied by a reduction in IL-10 [41, 61]. Corroborating these findings, our study showed significantly higher means in IL-10 levels in patients with OBI/HCV compared with controls.

In vivo levels of IL-6 have been associated with plasma ALT levels and the degree of liver fibrosis in patients with HCC in HCV monoinfected patients [71] and a previous study demonstrated a low detection rate of IL- 6 in patients infected with OBI when compared to healthy individuals and patients who resolved HBV infection [62]. We found high levels of IL-6 in the OBI/HCV group in our study and significant difference between $\mathrm{OBI} / \mathrm{HCV}$ compared to monoinfected HBV group and healthy controls, this increase in IL-6 expression could be attributed to HCV co-infection, since several studies have already found that this cytokine is associated with HCV chronic infection $[63,72,73]$.

It is well known that IL- 6 can play two important roles in the pathogenesis of hepatitis B, can protect the liver from virus infections by stimulating immune responses against infected hepatocytes and can inhibit the HBV entry in hepatocytes up to $90 \%$ when cells are treated with IL-6 resulting in a marked reduction in cccDNA and HBsAg secretion [74]. But the IL-6 can also play an important role in the induction of hepatitis, cirrhosis, and HCC $[33,75]$.

We found levels of IL-4 significantly increased in OBI/ HCV patients. IL- 4 is a cytokine that can suppress the Th1-type response, maintaining persistent HBV replication and promoting immune tolerance $[32,76,77]$. Some studies show that patients with severe hepatitis $C$ had higher levels of IL-4 compared to milder cases [78] and serum IL-4 levels were significantly increased in patients with chronic HCV [79].

Serum HBV DNA levels are typically low in occult hepatitis $B$, but despite the low rate of replication, detection of HBV DNA can be associated with ALT outbreaks that can be associated with advanced fibrosis/cirrhosis. In addition, occult $\mathrm{OBI} / \mathrm{HCV}$ coinfection is associated with decreased response to interferon [53].

There were some limitations in the present study. The biggest limitation was the low number of patients with OBI, but the most of studies with OBI and cytokines analyses from 12 to 30 samples [59, 62, 80]; the second limitation was that there are few studies on the cytokine production profile in patients with $\mathrm{OBI} / \mathrm{HCV}$ and finally, unfortunately, we could not include monoinfected $\mathrm{HCV}$ patients in our analyzes. However, our study was strongly compared to published data and can contribute to a better understanding of the complex response process related to cytokine production in OBI patients coinfected with $\mathrm{HCV}$.

\section{Conclusion}

In conclusion, the results of the present study suggest that there is a significant difference in the detection of IL-17A, TNF- $\alpha$, IL-10, IL-6, IL-4 and IL-2 in OBI/HCV patients when compared to healthy controls or HBV monoinfected. We found a high level of IL-17A in the HBV monoinfected group and high levels of TNF- $\alpha$, IL-10, IL-6, IL-4 and IL-2 in OBI/HCV patients. However, further studies are needed to better understand the complex regulatory mechanisms of the host inflammatory response related to cytokine production during OBI/ $\mathrm{HCV}$ coinfection and to understand the differences in mechanisms underlying infection resolution or the establishment of virus persistence. The expression of distorted cytokines exists in OBI patients coinfected with $\mathrm{HCV}$ and the exploration of this pattern of cytokine expression can help to develop a better understanding of the pathogenesis of chronic coinfection by $\mathrm{OBI}$ and $\mathrm{HCV}$.

\section{Supplementary Information}

The online version contains supplementary material available at https://doi. org/10.1186/s12985-021-01487-2.

Additional file 1. Data file of clinical and epidemiological information of patients with occult hepatitis B and HCV enrolled in this study. SAH (Subarachnoid hemorrhage); HCC (Hepatocellular carcinoma); IFN-Peg (Pegylated interferon); HBV (Hepatitis B virus); HCV (Hepatitis C virus); HAV (Hepatitis A virus); HIV (human immunodeficiency virus); IgG (Immunoglobulin G); HBsAg (Hepatitis B virus surface antigen); HBC (Antigen "C" or core of the hepatitis B virus); AST (alanine aminotransferase); ALT (alkaline phosphatase); GGT (gamma-glutamyl transferase); TGO (oxalacetic glutamic transaminase); TGP (glutamic-pyruvic transaminase); ALB (albumin); AFP (alpha-fetoprotein); LDL (Low Density Lipoproteins); HDL (High Density Lipoproteins); HGB (Hemoglobin); A.T (After treatment)

\section{Abbreviations}

HBV: Hepatitis B virus; OBI: Occult hepatitis B; IFN- $\gamma$ : Interferon gamma; TNF: Tumor necrosis factor; IL: Interleukin; HCV: Hepatitis C virus; DNA: Deoxyribonucleic acid; HCC: Hepatocellular carcinoma; cccDNA: Covalently closed circular DNA; HBsAg: Hepatitis B surface antigen; Anti-HBc: Antibody against the viral core; DAA: Direct-acting antivirals; EIA: Immunoenzymatic assays; PCR: Polymerase chain reaction; qPCR: Real-time PCR; AST: Aminotransferase; Alanine ALT: Aminotransferase; GGT: Gamma-glutamyl transferase; Cls: Confidence intervals; SD: Standard deviation; ND: Not determined; (SDF)-1a: Stromal cell-derived factor; CCR: C-C chemokine receptor; NK cell: Natural killer cells.

\section{Acknowledgements}

We would like to thank the Outpatient Clinic of Liver Disease at the Gaffrée and Guinle University Hospital (Rio de Janeiro, Brazil).

\section{Authors' contributions}

CRAR and VSdeP: Conceptualization, Methodology; CRAR, NAAA and KGM: Formal analysis, Data Curation; CRAR: Investigation, Validation; VSdeP, MAP 
and CEBM: Resources; CRAR: Writing-Original Draft; CRAR, VSdeP, CEBM and JJB: Writing—Review \& Editing; CRAR: Visualization; VSdeP and JJB: Supervision; VSdeP: Project administration, Funding acquisition. All authors read and approved the final manuscript.

\section{Funding}

This work was supported by Coordination for the Improvement of Higher Education Personnel (CAPES) and the Oswaldo Cruz Foundation.

\section{Availability of data and materials}

The dataset is available from the corresponding author.

\section{Ethics approval and consent to participate}

The study protocol was approved by the Research Ethics Committee of the Institute Oswaldo Cruz (CAAE 34246914.4.1001.5248 number 2.927.747/18).

\section{Consent for publication}

Not applicable.

\section{Competing interests}

The authors declared that, this study is without conflicts of interests.

\section{Author details}

${ }^{1}$ Laboratory of Molecular Virology, Oswaldo Cruz Institute, Oswaldo Cruz Foundation, 4365, Brasil Av., Manguinhos, Rio de Janeiro, RJ 21040-360, Brazil.

${ }^{2}$ Federal University of Espírito Santo, Espírito Santo, Brazil. ${ }^{3}$ Gaffrée and Guinle Universitary Hospital, Ambulatory of Liver Disease, Rio de Janeiro State Federal University/UniRio, Rio de Janeiro, Brazil.

Received: 23 June 2020 Accepted: 2 January 2021

Published online: 12 January 2021

\section{References}

1. Franco E, Bagnato B, Marino MG, Meleleo C, Serino L, Zaratti L. Hepatitis B: epidemiology and prevention in developing countries. World J Hepatol. 2012; 74-80.

2. WHO - World Health Organization 2017. Global hepatitis report, 2017. Available online: https://www.who.int/hepatitis/publications/globa I-hepatitis-report2017/en/. Accessed on 24 April 2020.

3. Shi M, Wei J, Dong J, Meng W, Ma J, Wang T, et al. Function of interleukin 17 and 35 in the blood of patients with hepatitis B related liver cirrhosis. Mol Med Rep 2015; 121-126.

4. Hu KQ. Occult hepatitis B virus infection and its clinical implications. J Viral Hepat. 2002; 243-257.

5. Raimondo G, Caccamo G, Filomia R, Pollicino T. Occult HBV infection. Semin Immunopathol. 2013;35:39-52.

6. Raimondo G, Locarnini S, Pollicino T, Levrero M, Zoulim F, Lok AS, et al. Update of the statements on biology and clinical impact of occult hepatitis B virus infection. J Hepatol. 2019;71:397-408.

7. Zobeiri M. Occult hepatitis B: clinical viewpoint and management. Hepat Res Treat 2013; 259148.

8. Sowole L, Labbett W, Patel M, O'Riordan A, Cross J, Davenport A, et al. The prevalence of occult hepatitis B virus (HBV) infection in a large multiethnic haemodialysis cohort. BMC Nephrol. 2015;16:12.

9. Vitale F, Tramuto F, Orlando A, Vizzini G, Meli V, Cerame G, et al. Can the serological status of anti-HBC alone be considered a sentinel marker for detection of occult HBV infection? J Med Virol. 2008:80:577-82.

10. Urbani S, F Fagnoni, Missale G, Franchini M. The role of anti-core antibody response in the detection of occult hepatitis B virus infection. Clin Chem Lab Med. 2010; 48:23-9.

11. Torbenson M, Thomas DL. Occult hepatitis B. Lancet Infect Dis. 2002;2:479-86.

12. Gerlich WH, Bremer C, Saniewski M. Schüttler CG, Wend UC, Willems WR, et al. Occult hepatitis B virus infection: detection and significance. Dig Dis 2010; 28.

13. Cheng HR, Kao JH, Wu HL, Chen TC, Tseng TC, Liu CH, et al. Clinical and virological features of occult hepatitis B in patients with $\mathrm{HBs} A g$ seroclearance post-treatment or spontaneously. Liver Int. 2014;34:e71-9.
14. Yip TC, Wong GL. Current knowledge of occult hepatitis B infection and clinical implications. Semin Liver Dis. 2019;39:249-60.

15. Said ZN. An overview of occult hepatitis B virus infection. World J Gastroenterol. 2011;17:1927-38.

16. Samal J, Kandpal M, Vivekanandan P. Molecular mechanisms underlying occult hepatitis B virus infection. Clin Microbiol Rev. 2012;25:142-63.

17. Kim MH, Kang SY, Lee WI. Occult HBV among anti-HBc alone: mutation analysis of an HBV surface gene and pre-S gene. Yonsei Med J. 2017;58:557-63.

18. Mücke MM, Backus LI, Mücke VT, Coppola N, Preda CM, Yeh ML, et al. Hepatitis B virus reactivation during direct-acting antiviral therapy for hepatitis C: a systematic review and meta-analysis. Lancet Gastroenterol Hepatol. 2018;3:172-80.

19. Honarkar Z, Alavian SM, Samiee S, Saeedfar K, Zali MR. Occult hepatitis B among chronic liver disease patients. Saudi Med J. 2005;26:601-6 (PMID: 15900369).

20. Takeda H, Takai A, Inuzuka T, Marusawa H. Genetic basis of hepatitis virus associated hepatocellular carcinoma: linkage between infection, inflammation, and tumorigenesis. J Gastroenterol. 2017;52:26-38.

21. Emara MH, El-Gammal NE, Mohamed LA, Bahgat MM. Occult hepatitis B infection in egyptian chronic hepatitis $C$ patients: prevalence, impact on pegylated interferon/ribavirin therapy. Virol J. 2010;17:324.

22. Squadrito G, Cacciola I, Alibrandi A, Pollicino T, Raimondo G. Impact of occult hepatitis B virus infection on the outcome of chronic hepatitis $C$. J Hepatol. 2013;59:696-700.

23. Coppola N. Role of occult hepatitis B virus infection in chronic hepatitis $C$. World J Gastroenterol. 2015;21:11931-40.

24. Ferrari C, Penna A, Bertoletti A, Valli A, Antoni AD, Giuberti T, et al. Cellular immune response to hepatitis $B$ virus-encoded antigens in acute and chronic hepatitis B virus infection. J Immunol. 1990;145:3442-9.

25. Jung MC, Hartmann B, Gerlach JT, Diepolder H, Gruber R, Schraut W. Virus-specific lymphokine production differs quantitatively but not qualitatively in acute and chronic hepatitis B infection. Virology. 1999;261:165-72.

26. Sobao Y, Tomiyama H, Sugi K, Tokunaga M, Ueno T, Saito S, et al. The role of hepatitis B virus-specific memory CD8 T cells in the control of viral replication. J Hepatol. 2002;36:105-15.

27. Chang JJ, Wightman F, Bartholomeusz A, Ayres A, Kent SJ, Sasadeusz J, et al. Reduced hepatitis B virus (HBV)-specific CD4+ T-cell responses in human immunodeficiency virus type 1-HBV-coinfected individuals receiving HBV-active antiretroviral therapy. J Virol. 2005;79:3038-51.

28. Zhang Z, Zhang JY, Wang LF, Wang FS. Immunopathogenesis and prognostic immune markers of chronic hepatitis B virus infection. J Gastroenterol Hepatol. 2012;27:223-30.

29. Chisari FV, Isogawa M, Wieland SF. Pathogenesis of hepatitis B virus infection. Pathol Biol. 2010;58(4):258-66.

30. Huang Z, van Velkinburgh JC, Ni B, Wu Y. Pivotal roles of the interleukin23/T helper 17 cell axis in hepatitis B. Liver Int. 2012;32:894-901.

31. Bauer T, Sprinzl M, Protzer U. Immune control of hepatitis B virus. Dig Dis. 2011;29:423-33.

32. Li Y, Wang Y, Liu Y, Wang Y, Zuo X, Li Y, Lu X. The possible role of the novel cytokines IL-35 and IL-37 in inflammatory bowel disease. Mediators Inflamm. 2014:13:63-29.

33. Barathan M, Mariappan V, Shankar EM, Abdullah BJ, Goh KL, Vadivelu J. Hypericin-photodynamic therapy leads to interleukin-6 secretion by HepG2 cells and their apoptosis via recruitment of $\mathrm{BH} 3$ interactingdomain death agonist and caspases. Cell Death Dis. 2013;4:e697.

34. Valaydon Z, Pellegrini M, Thompson A, Desmond P, Revill P, Ebert G. The role of tumour necrosis factor in hepatitis B infection: Jekyll and Hyde. Clin Transl Immunol. 2016;5(12):e115.

35. Das A, Ellis G, Pallant C, Lopes AR, Khanna P, Peppa D, et al. IL-10-producing regulatory $B$ cells in the pathogenesis of chronic hepatitis $B$ virus infection. J Immunol. 2012;189:3925-35.

36. Du WJ, Zhen JH, Zeng ZQ, Zheng ZM, XuY, Qin LY, et al. Expression of interleukin-17 associated with disease progression and liver fibrosis with hepatitis B virus infection: IL-17 in HBV infection. Diagn Pathol. 2013;28(8):40

37. Portilho MM, Mendonca A, Bezerra CS, Do Espirito-Santo MP, De Paula VS, Nabuco LC, et al. Usefulness of in-house real time PCR for HBV DNA quantification in serum and oral fluid samples. J Virol Methods. 2018;256:100-6. 
38. Guindon S, Dufayard JF, Lefort V, Anisimova M, Hordijk W, Gascuel O. New Algorithms and Methods to Estimate Maximum-Likelihood Phylogenies: Assessing the Performance of PhyML 3.0. Syst Biol. 2010; 59(3):307-321.

39. Anisimova M, Gascuel O. Approximate likelihood-ratio test for branches : a fast, accurate, and powerful alternative. Syst Biol. 2006;55(4):539-52

40. Alencar RS, Gomes MM, Sitnik R, Pinho JR, Malta FM, Mello IM, et al. Low occurrence of occult hepatitis B virus infection and high frequency of hepatitis $C$ virus genotype 3 in hepatocellular carcinoma in Brazil. Braz J Med Biol Res. 2008;41:235-40.

41. Branco F, Mattos AA, Coral GP, Vanderborght B, Santos DE, Franca P, et al. Occult hepatitis B virus infection in patients with chronic liver disease due to hepatitis $C$ virus and hepatocellular carcinoma in Brazil. Arq Gastroenterol. 2007;44:58-63.

42. Fontenele AM, Gainer JB, Da Silva ESDV, Cruz Santos MD, Salgado JV, Filho $\mathrm{N}$, et al. Occult hepatitis B among patients with chronic renal failure on hemodialysis from a capital city in northeast Brazil. Hemodial Int. 2015;19:353-9.

43. Motta JS, Mello FC, Lago BV, Perez RM, Gomes SA, Figueiredo FF. Occult hepatitis $B$ virus infection and lamivudine-resistant mutations in isolates from renal patients undergoing hemodialysis. J Gastroenterol Hepatol. 2010;25:101-6.

44. Pereira JS, Goncales NS, Silva C, Lazarini MS, Pavan MH, Fais VC, et al. HBV vaccination of HCV-infected patients with occult HBV infection and anti-HBc-positive blood donors. Braz J Med Biol Res. 2006;39:525-31.

45. Peres AA, Dias EA, Chesky M, Alvares-da-Silva MR, Jobim LF, Goncalves LF, Manfro RC. Occult hepatitis B in renal transplant patients. Transpl Infect Dis. 2005;7:51-6.

46. Rosa AS, Araujo OC, Savassi-Ribas F, Fernandes CA, Coelho HS, et al. Prevalence of occult hepatitis $B$ virus infection and torque teno virus infection and their association with hepatocellular carcinoma in chronic hepatitis C patients. Virus Res. 2017;15:166-72.

47. Hou J, Wang Z, Cheng J, Lin Y, Lau GK, Sun J, et al. Prevalence of naturally occurring surface gene variants of hepatitis $B$ virus in nonimmunized surface antigen-negative Chinese carriers. Hepatology. 2001:34:1027-34.

48. Raimondo G, Pollicino T, Squadrito G. What is the clinical impact of occult hepatitis B virus infection? Lancet. 2005:365:638-40.

49. Kim MJ, Kwon OS, Chung NS, Lee SY, Jung HS, Park DK, et al. The significance of anti-HBC and occult hepatitis B virus infection in the occurrence of hepatocellular carcinoma in patients with $\mathrm{HBsAg}$ and anti- HCV negative alcoholic cirrhosis. Korean J Hepatol. 2008;14:67-76.

50. Nishikawa H, Osaki Y. Clinical significance of occult hepatitis B infection in progression of liver disease and carcinogenesis. J Cancer. 2013:4:473-80

51. Shi Y, Wu YH, Wu W, Zhang WJ, Yang J, Chen Z. Association between occult hepatitis B infection and the risk of hepatocellular carcinoma: a meta-analysis. Liver Int. 2012;32:231-40.

52. Fernandez-Rodriguez CM, Gutierrez ML, Lledo JL, Casas ML. Influence of occult hepatitis B virus infection in chronic hepatitis $C$ outcomes. World J Gastroenterol. 2011;17:1558-62.

53. Fukuda R, Ishimura N, Hamamoto S, Moritani M, Uchida Y, Ishihara S, et al. Coinfection by serologically-silent hepatitis B virus may contribute to poor interferon response in patients with chronic hepatitis $C$ by down-regulation of type-l interferon receptor gene expression in the liver. J Med Virol. 2001;63:220-7.

54. Fukuda R, Ishimura N, Niigaki M, Hamamoto S, Satoh S, Tanaka S, et al. Serologically silent hepatitis B virus co-infection in patients with hepatitis C virus-associated chronic liver disease: clinical and virological significance. J Med Virol. 1999;58:201-7.

55. Kazemi-Shirazi L, Petermann D, Muller C. Hepatitis B virus DNA in sera and liver tissue of HBsAg negative patients with chronic hepatitis C. J Hepatol. 2000;33:785-90.

56. Chemin I, Zoulim F, Merle P, Arkhis A, Chevallier M, Kay A, et al. High incidence of hepatitis $B$ infections among chronic hepatitis cases of unknown aetiology. J Hepatol. 2001;34:447-54.
57. De Maria N, Colantoni A, Friedlander L, Leandro G, Idilman R, Harig J, et al. The impact of previous HBV infection on the course of chronic hepatitis C. Am J Gastroenterol. 2000;95:3529-36.

58. Sagnelli E, Coppola N, Scolastico C, Mogavero AR, Filippini P, Piccinino F. HCV genotype and "silent" HBV co-infection: two main risk factors for a more severe liver disease. J Med Virol. 2001;64:350-5.

59. Martin CM, Welge JA, Shire NJ, Shata MT, Sherman KE, Blackard JT. Cytokine expression during chronic versus occult hepatitis B virus infection in HIV co-infected individuals. Cytokine. 2009;47:194-8.

60. Germanidis G, Hytiroglou P, Zakalka M, Settas L. Reactivation of occult hepatitis $B$ virus infection following treatment of refractory rheumatoid arthritis with abatacept. J Hepatol 2012; 56:1420-1421. https://doi. org/10.1016/j.jhep.2011.10.011

61. Han ZQ, Huang T, Deng YZ, Zhu GZ. Expression profile and kinetics of cytokines and chemokines in patients with chronic hepatitis C. Int J Clin Exp Med. 2015;15:17995-8003 (PMID: 26770394).

62. Fierro NA, Roman S, Realpe M, Hernandez-Nazara Z, Zepeda-Carrillo EA Panduro A. Multiple cytokine expression profiles reveal immune-based differences in occult hepatitis B genotype H-infected Mexican Nahua patients. Mem Inst Oswaldo Cruz. 2011;106:1007-13.

63. Tarragô AM, da Costa AG, Pimentel JP, Gomes STM, Freitas FB, Lalwani P, et al. Combined impact of hepatitis $C$ virus genotype 1 and interleukin-6 and tumor necrosis factor-a polymorphisms on serum levels of pro-inflammatory cytokines in Brazilian HCV-infected patients. Hum Immunol. 2014;75(11):1075-83.

64. Xiao P, Chen QF, Yang YL, Guo ZH, Chen H. Serum soluble interleukin-2 receptor levels in patients with chronic hepatitis $B$ virus infection and its relation with anti-HBc. World J Gastroenterol. 2006;12:482-4.

65. Baskic D, Vukovic VR, Popovic S, Djurdjevic P, Zaric M, Nikolic I, et al. Cytokine profile in chronic hepatitis C: an observation. Cytokine. 2017;96:185-8.

66. Ma WT, Yao XT, Peng Q, Chen DK. The protective and pathogenic roles of IL-17 in viral infections: friend or foe? Open Biol. 2019;9(7):190109.

67. Wu JF, Wu TC, Chen $\mathrm{CH}, \mathrm{Ni}$ YH, Chen HL, Hsu HY, et al. Serum levels of interleukin-10 and interleukin-12 predict early spontaneous hepatitis B virus e antigen seroconversion. Gastroenterology. 2010;138(165-172):e161-3.

68. Fenoglio D, Bernuzzi F, Battaglia F, Parodi A, Kalli F, Negrini S, et al. Th17 and regulatory $T$ lymphocytes in primary biliary cirrhosis and systemic sclerosis as models of autoimmune fibrotic diseases. Autoimmun Rev. 2012;12:300-4.

69. Zhang JY, Zhang Z, Lin F, Zou ZS, Xu RN, Jin L, et al. Interleukin-17-producing CD4(+) T cells increase with severity of liver damage in patients with chronic hepatitis B. Hepatology. 2010;51:81-91.

70. Arababadi MK, Ahmadabadi BN, Kennedy D. Current information on the immunologic status of occult hepatitis B infection. Transfusion. 2012;52:1819-26.

71. Cachem FCOF, Dias AS, Monteiro C, Castro JR, Fernandes G, Delphim L, et al. The proportion of different interleukin-17-producing T-cell subsets is associated with liver fibrosis in chronic hepatitis C. Immunology. 2017;151:167-76.

72. Lapiński TW. The levels of IL-1 beta, IL-4 and IL-6 in the serum and the liver tissue of chronic HCV-infected patients. Arch Immunol Ther Exp (Warsz). 2001;49(4):311-6.

73. Shah S, Ma Y, Scherzer R, Huhn G, French AL, Plankey M, et al. Association of HIV, hepatitis C virus and liver fibrosis severity with interleukin- 6 and C-reactive protein levels. AIDS. 2015;29(11):1325-33.

74. Bouezzedine F, Fardel O, Gripon P. Interleukin 6 inhibits HBV entry through NTCP down regulation. Virology. 2015;481:34-42.

75. Klein C, Wu“sterfeld T, Assmus U, Roskams T, Rose-John S, Mueller M, et al. The IL-6-gp130-STAT3 pathway in hepatocytes triggers liver protection in T cell-mediated liver injury, J Clin Invest 2005; 115:860-869.

76. Nelms K, Keegan AD, Zamorano J, Ryan JJ, Paul WE. The IL-4 receptor: signaling mechanisms and biologic functions. Annu Rev Immunol. 1999;17:701-38.

77. Yao Y, Li J, Lu Z, Tong A, Wang W, Su X, et al. Proteomic analysis of the interleukin-4 (IL-4) response in hepatitis B virus-positive human hepatocelluar carcinoma cell line HepG2.2.15. Electrophoresis 2011; 32:2004-2012 
78. Zhang L, Hao CQ, Miao L, Dou XG. Role of Th1/Th2 Cytokines in serum on the pathogenesis of chronic hepatitis $C$ and the outcome of interferon therapy. Genet Mol Res. 2014;13:9747-55.

79. Abayli B, Canataroğlu A, Akkiz H. Serum profile of T helper 1 and T helper 2 cytokines in patients with chronic hepatitis $C$ virus infection. Turk J Gastroenterol. 2003;14(1):7-11.

80. Bes M, Vargas V, Piron M, Casamitjana N, Esteban Jl, Vilanova N, et al. T cell responses and viral variability in blood donation candidates with occult hepatitis B infection. J Hepatol. 2012;56:765-74.

\section{Publisher's Note}

Springer Nature remains neutral with regard to jurisdictional claims in published maps and institutional affiliations.
Ready to submit your research? Choose BMC and benefit from:

- fast, convenient online submission

- thorough peer review by experienced researchers in your field

- rapid publication on acceptance

- support for research data, including large and complex data types

- gold Open Access which fosters wider collaboration and increased citations

- maximum visibility for your research: over $100 \mathrm{M}$ website views per year

At BMC, research is always in progress.

Learn more biomedcentral.com/submissions 